\section{High Zinc Concentrations in the Growing Medium Contribute to Chlorosis in Blueberry}

\author{
Creighton L. Gupton ${ }^{1}$ and James M. Spiers ${ }^{2}$ \\ U.S. Department of Agriculture, Agricultural Research Service, Small Fruit \\ Research Station, Poplarville, MS 39470 \\ Additional index words. Vaccinium ashei, Vaccinium corymbosum, micronutrients, $\mathrm{pH}$, \\ phytotoxicity, Fe chlorosis
}

\begin{abstract}
An experiment arranged in a randomized complete block design with four replications of two cultivars $\times$ six $\mathrm{pH}$ levels $\times$ four $\mathrm{Zn}$ levels was conducted to determine if $\mathrm{Zn}$ caused leaf chlorosis in rabbiteye (Vaccinium ashei Reade cv. Climax) and southern highbush (mostly V. corymbosum L. cv. Bladen) blueberry. 'Bladen' accumulated more foliar Mn and Zn than 'Climax', but Fe concentration was similar in the two cultivars. Leaf chlorosis ratings were similar for the two cultivars. Solution $\mathrm{pH}$ had no significant effect on Mn, Zn, or Fe leaf concentration or degree of chlorosis. Zinc level in the nutrient solution affected leaf concentration of $\mathrm{Mn}$ and $\mathrm{Zn}$ but not of Fe. A significant linear increase in chlorosis resulted from increasing $\mathrm{Zn}$ solution concentration from 30 to 120 $\mathrm{mg} \cdot \mathrm{L}^{-1}$. We conclude that high levels of $\mathrm{Zn}$ may induce leaf chlorosis in rabbiteye and southern highbush blueberry.
\end{abstract}

Iron chlorosis of blueberry has been observed on mineral soils since the 1930s (Bailey, 1936) and its causes have not yet been fully elucidated. At low soil $\mathrm{pH}$, a requirement for blueberry culture, $\mathrm{Zn}$ can cause phytotoxicity directly and by increasing translocation of Mn to plant leaves in other crops (Chaney and Giordano, 1977). We have observed that almost all soil test results from small-fruit plantings in southern Mississippi indicate high or very high $\left(3-5 \mathrm{~kg} \cdot \mathrm{ha}^{-1}\right)$ soil $\mathrm{Zn}$ content, yet $\mathrm{Zn}$ deficiency has been reported prevalent in the lower Gulf Coastal Plain region of the United States (Beeson, 1957). Pettry and Switzer (1993) found 34-183 ppm $\mathrm{Zn}$ in the surface horizon of Lower Coastal Plains soils in Mississippi. Zinc deficiency in tung (Aleurites fordii Hemsl.) trees was a problem in this area and was usually corrected by applying 56-112 $\mathrm{g}$ of zinc sulfate per tree (Barrows et al., 1960). The tung belt extended from eastern Texas along the Gulf of Mexico to the Atlantic Ocean and included about 81,000 ha (Kilby, 1970), indicating that much $\mathrm{Zn}$ was applied where blueberries are grown currently. The objective of our study was to determine if excessive $\mathrm{Zn}$ in the growing medium causes chlorosis in blueberry.

\section{Materials and Methods}

Two-year-old plants of 'Climax' rabbiteye (RE) and 'Bladen' southern highbush (SHB) were root-washed and transplanted into 8-L

Received for publication 29 Jan. 1996. Accepted for publication 29 June 1996. The cost of publishing this paper was defrayed in part by the payment of page charges. Under postal regulations, this paper therefore must be hereby marked advertisement solely to indicate this fact.

${ }^{1}$ Research Geneticist.

${ }^{2}$ Research Horticulturist. pots of washed sand. All plants were fertilized with STEM (Soluble Trace Element Mix, Grace-Sierra Horticultural Products, Milpitas, Calif.) at $500 \mathrm{~mL} /$ pot and Osmocote $(14 \mathrm{~N}-$ 6P-12K) (Grace-Sierra Horticultural Products) at $20 \mathrm{~g} /$ pot 1 week before $\mathrm{Zn}$ applications were started.

Treatments were arranged in a randomized complete block with four replications of two cultivars $\times$ six solution $\mathrm{pH}$ levels $\times$ four solution $\mathrm{Zn}$ levels. The $\mathrm{pH}$ levels were 4.0, 4.5, 5.0, 5.5, 6.0, and 6.5 and $\mathrm{Zn}$ was at 30, 60, 90, and $120 \mathrm{mg} \cdot \mathrm{L}^{-1}$ from zinc sulfate and STEM. Three milligrams per liter of the total $\mathrm{Zn}$ in each treatment was supplied by STEM and the remainder was supplied by $\mathrm{ZnSO}_{4} \cdot 7 \mathrm{H}_{2} \mathrm{O}$. The $\mathrm{Zn}+$ STEM solutions were applied at $500 \mathrm{ml} /$ pot every 2-5 days, as irrigation was needed, from 18 May until 1 Aug. 1994.

Degree of leaf chlorosis on a wholeplant basis was rated visually by two persons (26 July and 29 July 1994) on a scale of $1=$ most chlorotic to $9=$ least chlorotic . Means of the two visual ratings were used as data for analysis. variables.

${ }^{\mathrm{z}}$ Leaf Fe concentration was unaffected by any source of variation.
All leaves from each plant were collected 3 Aug. 1994 and oven-dried at $70^{\circ} \mathrm{C}$. The leaves were ground and dry-ashed using the procedures of Jones and Case (1990) with the following modifications: 1) $1 \mathrm{~g}$ of tissue was weighed and ashed at $450^{\circ} \mathrm{C} ; 2$ ) the ash was dissolved in $5 \mathrm{ml}$ of $20 \% \mathrm{HCl}$ on a hot plate; and 3 ) the solution was transferred to a volumetric flask and brought to $100 \mathrm{ml}$ with deionized water. Manganese, $\mathrm{Zn}$, and Fe concentrations were determined by atomic absorption (Instrumentation Laboratory 157AA/AE spectrophotometer, Wilmington, Mass.).

Manganese, $\mathrm{Zn}$, and Fe leaf concentrations and leaf chlorosis ratings were analyzed statistically by general linear model procedures (SAS Institute, Cary, NC). Main effects of cultivar, $\mathrm{pH}$, and $\mathrm{Zn}$ concentration and their interactions were determined. Zinc concentration effects were subdivided into linear, quadratic, and cubic effects. Cultivar means were pooled across $\mathrm{pH}$ and $\mathrm{Zn}$ levels because there were no significant interactions with these sources. Likewise, leaf Mn and Zn concentrations and leaf chlorosis ratings were pooled across cultivars and $\mathrm{pH}$ levels.

\section{Results and Discussion}

Zinc and Mn leaf concentration differed significantly between RE and SHB cultivars (Table 1). No treatment interaction was significant. 'Bladen' (SHB) accumulated more foliar Mn and Zn than 'Climax' (RE), but Fe concentration was about the same for the two cultivars (Fig. 1). Field-grown SHB plants accumulated more $\mathrm{Mn}$ and about the same amounts of $\mathrm{Fe}$ and $\mathrm{Zn}$ as did RE plants (Clark et al., 1994). Zinc level was low in the soils where their plants were grown. Our results and those of Clark et al. imply that SHB may be more susceptible than RE to $\mathrm{Mn}$ and $\mathrm{Zn}$ toxicity when these elements are available in excessive amounts. Several authors, as reported by Chaney and Giordano (1977), have shown that when excessive $\mathrm{Zn}$ is added, chlorosis may occur in leaves containing apparently normal Fe levels. Korcak (1989) found high micronutrient $(\mathrm{Cu}, \mathrm{Zn}, \mathrm{Mn}$, and B) levels associated with Fe chlorosis in blueberry.

Solution $\mathrm{pH}$ had no significant effect on $\mathrm{Zn}, \mathrm{Fe}$, or Mn leaf concentration or degree of leaf chlorosis, nor were any interactions of $\mathrm{pH}$

Table 1. Effects of cultivar, $\mathrm{pH}$, and $\mathrm{Zn}$ concentration in nutrient solution, and their interactions on four

\begin{tabular}{|c|c|c|c|c|}
\hline \multirow[b]{2}{*}{ Source } & \multirow[b]{2}{*}{ df } & \multicolumn{2}{|c|}{ Leaf concn ${ }^{z}$} & \multirow{2}{*}{$\begin{array}{c}\text { Leaf } \\
\text { chlorosis }\end{array}$} \\
\hline & & $\mathrm{Zn}$ & $\mathrm{Mn}$ & \\
\hline$\overline{\text { Cultivar (C) }}$ & 1 & $* *$ & $* *$ & NS \\
\hline Replication & 3 & NS & NS & NS \\
\hline $\mathrm{pH}$ & 5 & NS & NS & NS \\
\hline ppm Zn & 3 & $* *$ & $*$ & $* *$ \\
\hline Linear & 1 & $* *$ & $* *$ & $* *$ \\
\hline Quadratic & 1 & NS & NS & NS \\
\hline Cubic & 1 & $* *$ & NS & NS \\
\hline $\mathrm{C} \times \mathrm{pH}$ & 5 & NS & NS & NS \\
\hline $\mathrm{C} \times$ ppm $\mathrm{Zn}$ & 3 & NS & NS & NS \\
\hline $\mathrm{pH} \times \mathrm{ppm} \mathrm{Zn}$ & 15 & NS & NS & NS \\
\hline $\mathrm{C} \times \mathrm{pH} \times \mathrm{ppm} \mathrm{Zn}$ & 15 & NS & NS & NS \\
\hline
\end{tabular}

Ns, *, ** Nonsignificant or significant at $P \leq 0.05$ or 0.01 , respectively. 
by other sources of variation significant (Table 1). Soil $\mathrm{pH}$ is known to be a dominant factor in Zn uptake (Chaney and Giordano, 1977); however, absence of organic matter in sand culture probably removed $\mathrm{pH}$ influence over the extent of minor element reaction with the medium. Soil pHalso affects Zn diffusion (Chaney and Giordano, 1977), which is not a factor in sand culture. Solution $\mathrm{pH}$ in sand culture apparently does not play the same role as field soil $\mathrm{pH}$ in controlling minor element uptake.

Zinc concentration in the nutrient solution significantly affected $\mathrm{Zn}$ and $\mathrm{Mn}$ but not $\mathrm{Fe}$ leaf concentration (Table 1). Zinc leaf concentration increased but $\mathrm{Mn}$ concentration decreased linearly with increasing Zn level in the nutrient solution (Table 1). Except for leaf Zn concentration, no quadratic or cubic effect of solution Zn content was significant (Table 1). These results differ from those of Lee and Page (1967) and Lee and Craddock (1969) who found that soil additions of $\mathrm{Zn}$ in cotton (Gossypium hirsutum L.) and soybean (Glycine $\max$ L. Merr.) increased plant uptake of $\mathrm{Mn}$. In a leaf chlorosis amelioration study, Spiers and Braswell (1989) found higher leaf $\mathrm{Mn}$ in RE plants fertilized with $\mathrm{ZnSO}_{4}$ than those receiving Mn chelate. Korcak (1988) and Spiers (1990) reported that high Mn concentration in leaves resulted in poor plant growth and leaf chlorosis. A possible explanation of the differing results between plants grown in sand culture and the field may be soil organic matter effects on Mn and Zn interaction with the medium. It appears that high $\mathrm{Zn}$ levels in soil may cause increased Mn toxicity even though it would not be suggested from the results of this study.

Zinc concentration significantly affected the degree of leaf chlorosis (Table 1). A significant linear increase in chlorosis resulted from increasing $\mathrm{Zn}$ concentration between 30 and $120 \mathrm{mg} \cdot \mathrm{L}^{-1}$ (Table 1 ). In reviews of other crops, Foy et al. (1978) concluded that chlorosis from excess $\mathrm{Zn}$ appears to be due to direct or indirect interaction with foliar Fe. White et al. (1974) hypothesized that Zn and Mn interfere with Fe use for chlorophyll synthesis in the leaves. Since $\mathrm{Zn}$ solution concentration did not affect leaf Fe concentration, our results support the hypothesis of White et al. Iron concentrations in chlorotic leaves equal to or higher than those found in green leaves were reported in blueberry (Korcak, 1989). Leaf chlorosis rating was similar for the two cultivars we tested. We conclude that high levels of $\mathrm{Zn}$ in the growing medium may induce leaf chlorosis in RE and SHB blueberry.

\section{Literature Cited}

Bailey, J.S. 1936. A chlorosis of cultivated blueberries. Proc. Amer. Soc. Hort. Sci. 34:395-396.

Barrows, H.L., M.S. Neff, and N. Gammon, Jr.

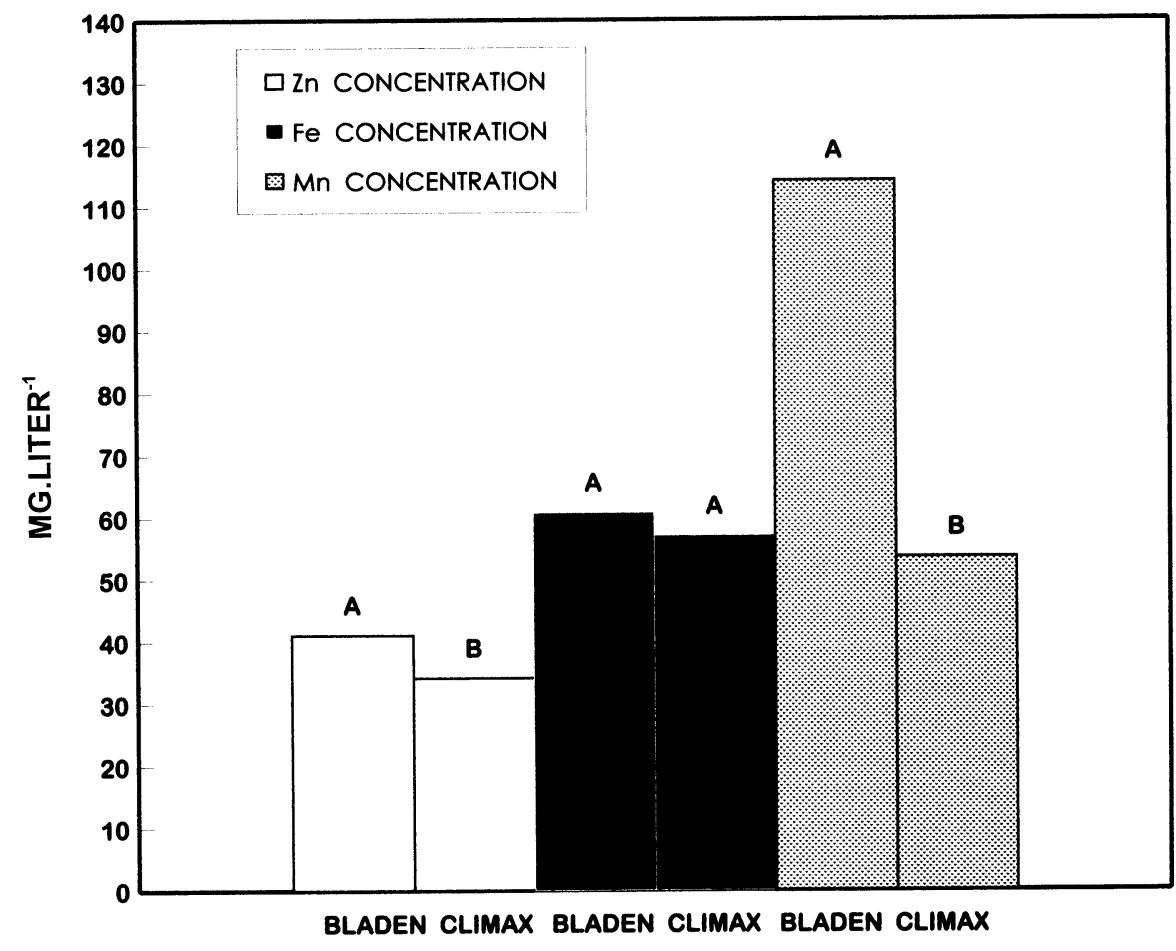

\section{CULTIVAR}

Fig. 1. Leaf micronutrient concentration of 'Bladen' (southern highbush type) and 'Climax' (rabbiteye type) blueberry plants averaged across four replications, six $\mathrm{pH}$ levels, and four $\mathrm{Zn}$ levels. Mean squares for difference between cultivars were $2289(P>0.0007), 667$ (Ns), and 175,774 $(P>0.0001)$ for $\mathrm{Zn}, \mathrm{Fe}$, and $\mathrm{Mn}$, respectively.

1960. Effect of soil type on mobility of zinc in the soil and on its availability from zinc sulfate to tung. Soil Sci. Amer. Proc. 24:367-372.

Beeson, K.C. 1957. Soil management and crop quality, p. 258-267. In: Alfred Stefferud (ed.). Soil the 1957 yearbook of agriculture. U.S. Government Printing Office, Washington, D.C.

Chaney, R.L. and P.M. Giordano. 1977. Microelements as related to plant deficiencies and toxicities, p. 234-270. In: L. F. Elliot andF. J. Stevenson (eds.). Soils for management of organic wastes and waste waters. Soil Sci. Soc. Amer., Madison, Wis.

Clark, J.R., D.S. Creech, M.E. Austin, M.E. Ferree, P.M. Lyrene, C.M. Mainland, D.J. Makus, E.W. Neuendorff, K.D. Patten, and J.M. Spiers. 1994. Foliar elemental analysis of southern highbush, rabbiteye, and highbush blueberries in the southern United States. HortTechnology 4:351-355.

Foy, C.D., R.L. Chang, and M.C. White. 1978. The physiology of metal toxicity in plants. Annu. Rev. Plant Physiol. 29:511-566.

Jones, J.B., Jr., and V.W. Case. 1990. Sampling, handling, and analyzing plant tissue samples, $\mathrm{p}$. 389-427. In: R.L. Westerman (ed.). Soil testing and plant analysis. SSSA Book series 3. Soil Sci. Soc. Amer., Madison, Wis.

Kilby, W.W. 1970. The American tung nut industry. Agr. Sci. Rev. 8:29-35.

Korcak, R.F. 1988. Responses of blueberry species to excessive manganese. J. Amer. Soc. Hort. Sci. 113:189-193.

Korcak, R.F. 1989. Influence of micronutrient and phosphorus levels and chelator to iron ratio on growth, chlorosis, and nutrition of 'Bluecrop' highbush blueberries. J. Plant Nutr. 12:12931310.

Lee, C.R. and G.R. Craddock. 1969. Factors affecting plant growth in high-zinc medium: II. Influence of soil treatments on growth of soybeans on strongly acid soil containing zinc from peach sprays. Agron. J. 61:565-567.

Lee, C.R. and N.R. Page. 1967. Soil factors influencing the growth of cotton following peach orchards. Agron. J. 59:237-240.

Pettry, D.E. and R.E. Switzer. 1993. Heavy metal concentration in selected soils and parent materials in Mississippi. Miss. Agr. \& For. Expt. Sta. Res. Bul. 998.

Spiers, J.M. 1990. Influence of aluminum and manganese on rabbiteye blueberries. HortScience 25:515-516.

Spiers, J.M. and J.H. Braswell. 1989. Effects of sulfur and micronutrients on growth and elemental leaf content of rabbiteye blueberries. Acta Hort. 241:151-156.

White, M.C., R.L. Chaney, and A.M. Decker. 1974. Differential varietal tolerance in soybean to toxic levels of zinc in Sassafras sandy loam. Agron. Abstr. 1974:144-145. 